\title{
O DESENVOLVIMENTO DA ARQUITETURA GÓTICA A PARTIR DA FILOSOFIA ESCOLÁSTICA
}

\author{
Eduardo Pacheco Freitas ${ }^{\star}$ \\ Pontifícia Universidade Católica do Rio Grande do Sul - PUCRS
}

\begin{abstract}
This paper aims to explore the onset and peak of the development of Gothic architecture, religious art and architecture eminently urban, between the twelfth and thirteenth centuries in the medieval West, in a socio-religious Catholic hegemony. The message sent to the faithful through the Gothic architecture, replacing Romanesque, indicates in this case a major change in mindset, since we consider the importance of semiotics in art, architecture and urban space.
\end{abstract}

KEYWORDS: Gothic architecture; Scholastic philosophy; Medieval urbanism; Art History; Gothic cathedrals.

\section{Introdução}

uando se fala de Arquitetura Gótica, ou simplesmente da Arte Gótica em geral, a primeira imagem que nos vem à mente é sempre a de enormes catedrais, pontiagudas, apontando para o céu, grandes o suficiente para acolher a população de uma cidade inteira. No entanto, a arquitetura gótica representa na história do ocidente medieval muito mais do que simplesmente um novo estilo arquitetônico. É sim, uma revolução na forma de se construir, sobretudo igrejas, mas a sua importância vai mais além, tornando-se o símbolo de uma revolução religiosa, de uma mudança de mentalidade e de uma mensagem filosófica enviada, através da pedra das construções, pela arquitetura. E seu aparecimento está associado de maneira íntima ao desenvolvimento das cidades no período da Baixa Idade Média.

^ eduardo.freitas.001@acad.pucrs.br 
Metodologicamente, temos como objetivo neste trabalho explorar estas relações a partir do conceito de "locus" conforme expresso no livro $A$ arquitetura da cidade, ${ }^{1}$ que consiste na "relação singular mas universal que existe entre certa situação local e as construções que se encontram naquele lugar". ${ }^{2}$ Com isto, entendemos que o surgimento do estilo gótico está estreitamente ligado às especificidades do âmbito geográfico do continente europeu, mais precisamente na França setentrional.

Da mesma forma pretendemos estudar a relação existente entre o desenvolvimento da arquitetura gótica e o surgimento da filosofia escolástica, ${ }^{3}$ assim como procuraremos entender esta nova forma de arquitetura, surgida entre os séculos XII e XIII, como signo desta e de outras relações, e como fator de preservação da memória e registro do espírito de um período de transição de mentalidades.

\section{Transformações mentais e materiais nas cidades medievais}

Nos séculos XII e XIII aconteceram "profundas transformações nas estruturas materiais e mentais da sociedade europeia", ${ }^{4}$ inserindose neste contexto de transformação o surgimento do estilo gótico e da filosofia escolástica como fenômenos eminentemente urbanos situados em uma conjuntura religiosa e social hegemonicamente católica.

Ainda de acordo com Silveira, "o espaço urbano na Idade Média centralizou os principais equipamentos materiais e simbólicos do sagrado, [...] constituiu-se como paisagem e ambientação social fundamental para a proliferação das manifestações coletivas da espiritualidade cristã".

Embora a autora esteja se referindo de maneira mais específica aos movimentos da sociedade no sentido de se atingir "novos modelos da religiosidade urbana", ${ }^{6}$ ou seja, o desenvolvimento de ordens religiosas

\footnotetext{
${ }^{1}$ Cf. Rossi, op. cit.

${ }^{2}$ Cf. Rossi, op. cit., p. 147.
}

${ }^{3}$ Segundo o Dicionário de filosofia de Cambridge (São Paulo: Paulus, 2006, p. 286), a Escolástica é um conjunto de técnicas escolares e instrucionais desenvolvidas nas escolas das universidades da Europa Ocidental no final do período medieval, que inchíam o uso do comentário e da questão disputada.

${ }^{4}$ Cf. Silveira, op. cit., p. 165.

${ }^{5}$ Cf. Silveira, op. cit., p. 165-166.

${ }^{6}$ Cf. Silveira, op. cit., p. 167. 
populares que encontraram terreno fecundo neste novo panorama, de caráter urbano, que estava se tornando mais e mais complexo, podemos ampliar a interpretação do texto e aplicá-lo ao que aconteceu à época do surgimento da arquitetura gótica.

É inegável a influência que o grande desenvolvimento urbano destes dois séculos teve sobre a sociedade como um todo. Em relação à ligação íntima entre o que acontece nas cidades e o que elas aparentam externamente, Lopez diz que "visto o aspecto físico da cidade espelhar as intenções e as necessidades práticas dos cidadãos (e como negá-lo?), a sua estrutura e a sua evolução urbanística constituem uma província da sua história que não pode ser marginal".

Daí a importância de se reconhecer os efeitos sobre a arquitetura oriundos da evolução não somente material mas também mental das cidades e de se estabelecer estas relações como objeto de estudo historiográfico. Neste sentido, portanto, é que se faz necessário compreender que a passagem da arquitetura românica para a arquitetura gótica significa bem mais do que apenas uma mudança de estilo. As transformações religiosas e mentais daquela sociedade tiveram seu registro perfeito em suas obras arquitetônicas, e, logicamente, com mais impacto, nas construções dos grandes templos religiosos. As catedrais perderam seu aspecto de fortalezas e passaram a representar o transcendente, o contato com o divino. Sobre o surgimento do estilo gótico, Le Goff diz:

A arte gótica, que também foi chamada de arte francesa, inundou toda a Europa cristã, a partir da França do Norte e, mais particularmente, do centro dessa região, que se chamava a França propriamente dita, no século XIII, e mais tarde Île-de-France. Esta arte nova, muito diferente da romana, responde ao mesmo tempo a um grande crescimento demográfico, que reclama igrejas maiores, e a uma profunda mudança de gosto. Além das dimensões mais vastas, o gótico manifestou-se pela atração da verticalidade, da luz e até da cor.

O autor nos traz informações muito importantes: em primeiro lugar é feita a delimitação geográfica do surgimento da arquitetura gótica, situando-a na França setentrional (não por acaso o mesmo local onde surgiu a Escolástica, pois, como veremos mais à frente, existem teorias a respeito desta relação); em segundo lugar, a nova forma dada às construções, agora

\footnotetext{
${ }^{7}$ Cf. Lopez, op. cit., p. 96.

${ }^{8}$ Cf. Le Goff, op. cit., 1992, p. 205-206.
} 
maiores internamente e mais altas, que é importante, tanto por contentar uma nova necessidade estética, que indica claramente uma mudança de pensamento daquela sociedade em transição, quanto por poder acolher mais fiéis, já que estes aumentavam juntamente com o crescimento das cidades. Le Goff afirma que, "embora as causas demográficas não tenham sido mais que um dos fatores de substituição das antigas igrejas", este aspecto é importante, porém salienta que ele não é o único responsável pela mudança. ${ }^{9}$

Em face disso, podemos afirmar que à medida que o urbanismo se desenvolvia, havia uma mudança de gosto. E, ao mesmo tempo que a população crescia - e com isso surgia a exigência de templos maiores -, as antigas igrejas de aspecto soturno e militar não correspondiam mais aos valores religiosos e, consequentemente, estéticos, já que tratamos aqui da construção de edifícios destinados ao culto religioso.

$\mathrm{O}$ autor prossegue, informando sobre as características destas mudanças em termos arquitetônicos:

Nasceu uma Europa do gigantismo e da desmedida. Sempre mais alto! Esta parece ter sido a palavra de ordem dos arquitetos góticos. Depois de uma primeira geração de catedrais entre 1140 e 1190, marcada pelas catedrais de Sens, de Noyon e de Laon, o século XIII foi o grande século das catedrais, a começar por Notre-Dame de Paris. ${ }^{10}$

Esta busca desenfreada pela altura provocou uma espécie de competição entre os construtores de catedrais. Quem conseguiria construir a catedral mais alta? Devido a esta ânsia por verticalidade, acidentes aconteceram e obras desmoronaram. ${ }^{11}$ As naves tinham cada vez mais maiores dimensões verticais, como atestam as catedrais de Notre-Dame de Paris (35 metros), Reims (38 metros) e Notre-Dame de Amiens (42 metros). Além disso, era planejada também a relação entre largura e altura da nave, com objetivo de proporcionar sempre uma maior sensação de impulso para o alto, para os céus.

\footnotetext{
${ }^{9}$ Cf. Le Goff, op. cit., 1992, p. 211.

${ }^{10}$ Cf. Le Goff, op. cit., 1992, p. 206.

${ }^{11}$ Em 1225, na cidade de Beauvais, planejou-se construir o coro da catedral com uma altura de 48 metros, o que provocou o seu desabamento no ano de 1284 . (cf. Le Goff, op. cit., 1992, p. 211).
} 


\section{O desenvolvimento da arquitetura gótica: uma revolução arquitetônica e religiosa}

O estilo gótico surge quando o estilo românico mal havia se estabelecido, fazendo as igrejas deste último parecerem desprovidas de graça, com densidade exagerada e já obsoletas. A origem do termo "gótico", significando esta nova maneira de construção, está no fato de seu aparecimento ter sido fora da Itália e de ter funcionado como uma substituta da arquitetura românica, numa clara alusão a velha dicotomia do mundo civilizado e do mundo bárbaro, pois o termo remete aos godos. Neste sentido, Gozzoli diz: "é muito provável que os humanistas do Renascimento tenham adotado o termo gótico como sinônimo de bárbaro, no sentido de proveniente da região de além-Alpes, por oposição a românico". ${ }^{12}$

A grande descoberta da arquitetura gótica, em relação à arquitetura românica, foi o fato de se desenvolver o arco ogival, uma grande evolução, se comparado aos antigos arcos redondos românicos, justamente por permitir maior altura das abóbadas. Aliada a esta inovação há uma outra, diretamente relacionada a esta nova modalidade técnica: a distribuição uniforme de peso, que ajuda a reduzir o material necessário para a construção da obra. Não só o arrojo das linhas, destas paredes que transmitem a impressão de serem inteiramente construídas em vidro, importou para os construtores. Eles cuidaram também para que a proeza artística pudesse ser claramente sentida e aproveitada por quem vislumbrasse a construção. ${ }^{13}$

Afinal, a própria etimologia da palavra catedral revela a magnitude de tais obras (cathedra $=$ trono episcopal) ${ }^{14}$ pois estas não eram simplesmente igrejas, mas igrejas próprias dos bispos. Daí a importância atribuída à beleza das obras, já que, segundo Le Goff, esta foi uma "época em que o primeiro critério de beleza é o da grandeza" ${ }^{15}$ Desta forma, compreende-se a

\footnotetext{
${ }^{12}$ Cf. Gozzoli, op. cit., p. 3 .

${ }^{13}$ Um caso emblemático acerca da união de funcionalidade e beleza desenvolvida pelos construtores góticos foi a utilização dos vitrais, que, ao mesmo tempo, passavam a sensação de transcendentalidade e representavam os ensinamentos da Igreja. Segundo um religioso medieval citado por Gozzoli sem ser identificado, os vitrais ensinavam às pessoas simples que não conhecem as Escrituras aquilo em que devem crer (op. cit., p. 22). É uma perfeita junção de beleza e instrução, afinal trata-se aqui de uma sociedade que tem a maior parte de sua população analfabeta e suscetível a este tipo de estímulo.

${ }^{14}$ Cf. Gombrich, op. cit., p. 188.
${ }^{15}$ Cf. Le Goff, op. cit., 1992, p. 211.
} 
necessidade imperiosa de características de transcendentalidade e de utilização da luz natural, filtrada pelos vitrais, que construíam assim um ambiente celestial dentro dos templos.

Devido a toda esta imponência, poucas dessas edificações foram completadas conforme seus projetos originais, que eram por demais grandiosos:

\begin{abstract}
É difícil imaginar a impressão que esses edifícios devem ter causado àqueles que só tinham conhecido as pesadas e sombrias estruturas do estilo românico. Aquelas igrejas mais antigas, em sua força e poder, talvez transmitissem algo da Igreja Militante que oferecia abrigo e proteção contra as investidas do mal. As novas catedrais propiciavam aos fiéis o vislumbre de um mundo diferente. Eles teriam ouvido falar, em sermões e cânticos, da Jerusalém Celestial, com seus portões de pérolas, suas joias de ouro de incalculável preço, suas ruas de ouro puro e cristal transparente (Apocalipse, XXI). ${ }^{16}$
\end{abstract}

Gombrich salienta que "tudo que era pesado, terreno ou trivial fora eliminado"; assim como a escolástica fez em relação à exposição metodológica do conhecimento, a arquitetura gótica fez com as suas linhas. Diz, ainda, que o artista gótico, ao realizar sua obra, "não a narra apenas para divulgar, mas para nos transmitir uma mensagem, e para consolo e edificação dos fiéis". ${ }^{17}$

Havia uma tendência, à época, por parte dos frades pregadores, de estimular a imaginação dos fiéis que eram convidados a visualizar mentalmente as cenas dos evangelhos. Nada mais natural do que expor artisticamente e através das linhas inovadoras e escolásticas das catedrais góticas esta forma de evangelizar. Podemos, de modo similar, encarar esta maneira de tratar o tema da espiritualidade, a partir de construções imagéticas mentais, como uma maneira de promover a memorização dos temas evangélicos, um estratagema que visava a tornar estes

\footnotetext{
${ }^{16}$ Cf. Gombrich, op. cit., p. 188/ Podemos estabelecer uma interessante relação entre a novidade gótica que é a utilização da luz natural, filtrada pelos vitrais, e sua capacidade de provocar sentimentos transcendentais nos fiéis, com o texto do versículo 23 do último livro da Bíblia: A cidade não precisa nem do sol, nem da lua, para lhe darem claridade, pois a Glória de Deus a iluminou, e o Cordeiro é a sua lâmpada. Neste sentido, basta-nos recordar que, devido ao caráter hierofânico do homem medieval, havia o entendimento de que a luz provinha diretamente de Deus (cf. Gozzoli, op. cit., p. 22) e como tal é possível entendermos a importância da presença da luminosidade em um templo gótico.

${ }^{17}$ Cf. Gombrich, op. cit., p. 193.
} 
ensinamentos mais presentes, internalizados no cristão, em suma, uma forma de relembrar e perpetuar o conhecimento acerca dos evangelhos de um jeito mais lúdico e fácil.

Segundo Gombrich, devido ao espírito da época o objetivo era provocar as seguintes reflexões: "Como se portaria um homem, como agiria, como se impressionaria se participasse de tais eventos? Mais do que isso: como se apresentariam aos nossos olhos tais gestos ou movimentos?" ${ }^{18}$

Diferentemente da Igreja Militante do século anterior, com suas construções objetivando combater o mal e vencê-lo, como fortalezas da cristandade, as catedrais góticas do século XIII, afinal o século da Igreja Triunfante, traziam, em forma de pedra e vidro, o Reino dos Céus até a Terra e promoviam uma experiência sensorial nos fiéis de caráter metafísico e plena de religiosidade. Segundo Pugin, "o próprio plano do edifício é o símbolo da redenção humana”. ${ }^{19}$ Ele acrescenta que não bastava apenas criar e executar esta obra de arte arquitetônica sem haver sentidos maiores implícitos em cada pedra assentada e em cada imagem esculpida, pois,

[...] para que as construções produzam efeitos semelhantes sobre o espírito é preciso que seus autores tenham sido totalmente absorvidos pela fé e pela devoção, que a glorificação da religião tenha sido o próprio fim de sua educação. ${ }^{20}$

E é nesse sentido que o arquiteto, convertido ao catolicismo em 1833 e um dos promotores do renascimento gótico na Inglaterra, discorre acerca do sentimento e da filosofia que movia estes homens, desde o arquiteto ao pedreiro na execução de uma catedral:

Aqueles homens sentiam estar comprometidos com a ocupação mais gloriosa que possa caber a um homem, a de levantar um templo para a veneração do Deus da Verdade e da Vida. Este sentimento é que guiava ao mesmo tempo a mente que concebia os planos do edifício e o escultor paciente cujo cinzel recortava o detalhe admirável e diverso. Este sentimento é que levou os antigos pedreiros, apesar do perigo e das dificuldades da tarefa, a perseverar até que tivessem erguido suas flechas gigantescas numa região próxima das nuvens. ${ }^{21}$

\footnotetext{
${ }^{18}$ Cf. Gombrich, op. cit., p. 201-202.

${ }^{19}$ Cf. Pugin, op. cit., p. 118.

${ }^{20}$ Cf. Pugin, op. cit., p. 118.

${ }^{21}$ Cf. Pugin, op. cit., p. 118.
} 
Com isto, percebemos o quanto pode haver de coesão e determinação conjunta entre os diferentes estamentos - arquitetos, artistas, pedreiros, clérigos - quando há um objetivo comum que permeia toda a sociedade: levar a mensagem cristã adiante, preservando-a na arte, perpetuando-a na escultura e, de maneira mais perene, nas pedras que erguem as catedrais góticas até o céu. Esta imagem e este sentimento foram buscados à exaustão por todos aqueles envolvidos na realização de uma catedral gótica: causar a impressão de que o edifício se estende até o céu.

Contudo, Jacques Le Goff oferece uma visão que contrapõe este entendimento de Pugin em relação aos construtores de catedrais:

Não se deve crer, segundo o testemunho de certos textos célebres que mostram o entusiasmo das populações no sentido de contribuir para a reconstrução da catedral românica de Chartres, destruída por um incêndio em 1194, que as grandes catedrais do século XIII tenham sido construídas com o dinheiro e os incentivos dos burgueses. A ação financeira, artística e psicológica é essencialmente a dos bispos e dos cônegos, mais ou menos ajudados pelo rei e pelos príncipes territoriais. ${ }^{22}$

Ou seja, mais do que um evento de caráter absolutamente coletivo, de união de esforços, de sinergia pura e simples, de acordo com a visão de Le Goff, a construção das catedrais góticas foi um movimento, naturalmente, arquitetado de cima para baixo. Os clérigos, aliados à nobreza, contribuíram, mais do os que burgueses e muito mais, evidentemente, do que qualquer movimento espontâneo popular ligado a alguma forma de pregação evangélica, para que surgisse esse novo tipo de estrutura arquitetônica em pleno coração das cidades. Não se restringindo somente ao caráter financeiro, ao lançar a hipótese de que o dinheiro para as obras não vinha da burguesia, o autor vai ainda mais longe e afirma que justamente a ideia, a concepção do novo estilo parte quase exclusivamente do clero, com apoio maior ou menor da nobreza.

\section{IV.1. A influência da filosofia escolástica sobre a arquitetura gótica}

Nos anos 50 do século XX o pesquisador Erwin Panofsky expôs uma tese que estabeleceu uma inusitada ligação entre a filosofia escolástica e a arquitetura gótica. É sabido que ambas surgiram

${ }^{22}$ Cf. Le Goff, op. cit., 1992, p. 212. 
paralelamente no mesmo espaço geográfico, no caso o norte de Paris, e no mesmo período de tempo, aproximadamente entre os séculos XII e XIII. Panofsky vê nesta coincidência temporal e espacial dos dois eventos mais do que uma simples casualidade e defende a existência de uma relação mais concreta que a simples sincronia no tempo e no espaço. Aponta, entre outros fatores, uma provável influência de conselheiros escolásticos sobre os artistas e mestres ${ }^{23}$ góticos.

No entanto, o autor vai além e chega a uma conclusão mais profunda, defendendo a hipótese de que esta influência, muito mais do que de forma direta e individual, se deu genericamente, através do que ele chama de "hábito mental". Este conceito é entendido por Panofsky como "um princípio que rege a ação" e o autor sustenta seu pensamento com a simples constatação histórica de que "a escolástica detinha o monopólio da formação intelectual naquele âmbito restrito". ${ }^{24}$

Em geral, a educação espiritual deslocou-se das escolas monásticas para instituições mais urbanas que rurais, de caráter antes cosmopolita que regionalista e, por assim dizer, apenas semi-eclesiásticas, a saber: as escolas catedrais, as universidades e as studia das novas ordens mendicantes que surgiram quase todas no século XIII e cujos membros desempenharam papel de crescente importância mesmo nas universidades. ${ }^{25}$

Isto é, a educação e a produção de conhecimento não estavam mais restritas à clausura dos mosteiros. Deixava de existir o isolamento natural das práticas intelectuais que passaram então a acontecer também nas cidades.

Podemos imaginar em qual clima psicológico e intelectual passou a existir a arquitetura gótica: dentro da cidade, envolta pela fé e pela razão, com a missão de substituir uma arquitetura que não satisfazia mais à religiosidade católica, que agora contava com um complexo sistema filosófico como respaldo teológico e intelectual. Neste sentido, devemos atentar para as observações de Maria Gozzoli:

[...] a escolástica - que enquadrava harmoniosamente todo o saber do tempo e afirmava a possibilidade de ascender a Deus não só pela fé, como pela razão. Chegava-se a Deus por um esforço de

\footnotetext{
${ }^{23}$ Mestre era o nome que se dava ao arquiteto neste período.

${ }^{24}$ Cf. Panofsky, op. cit., p. 14-15.

${ }^{25}$ Cf. Panofsky, op. cit., p. 15.
} 
pensamento, complexo mas requintado, rigidamente formal mas rico de sutilezas: esses mesmos conceitos que, em arquitetura, inspiraram as catedrais góticas, a sua ascensão para Deus através de construções complexas mas requintadas, formalmente rigorosas, mas de igual modo ricas de pormenores. ${ }^{26}$

Aqui, as palavras-chave são: harmonia e ascensão; fé e razão; complexidade e requinte; formalidade e sutileza. São palavras que podem ser usadas tanto para caracterizar a escolástica quanto o gótico. Mais uma vez nos parece evidente a relação entre os dois fenômenos.

E sobre este contato, entre os mestres-construtores e os clérigos com os quais tinham que trabalhar, todos mergulhados em uma nova ambientação intelectual, Panofsky diz:

É pouco provável que os arquitetos do gótico tenham lido Gilberto de la Porrèe ou Tomás de Aquino no original. Mas entraram em contato com o ideário escolástico por inúmeros outros, sem perceber que, por força de sua atividade, tinham de trabalhar com quem esboçava os programas litúrgicos e iconográficos. Haviam frequentado a escola, tinham ouvido sermões e podiam acompanhar as disputationes de quolibet que tratavam de todas as questões imagináveis da atualidade e que se haviam transformado em eventos sociais, comparáveis a nossas óperas, concertos e conferências públicas. ${ }^{27}$

É feita uma ressalva: os mestres provavelmente não manusearam os livros que continham toda a essência do pensamento escolástico. Mas teriam sido fortemente influenciados por esta aura escolástica que dominava todo o ambiente. A escolástica estava no ar e os arquitetos do gótico estavam inseridos neste contexto.

\section{IV.2. Completude, ordenamento e clareza}

Existem três exigências mínimas e fundamentais para que se cumpra aquilo que é denominado pelos estudiosos de esquematismo ou de formalismo escolástico. A clareza é algo buscado incessantemente nos textos escolásticos e para se atingi-la de modo satisfatório deve-se utilizar: a completude, que é a enumeração suficiente - nem mais, nem menos - das questões a serem abordadas; o ordenamento seguindo o esquema de "partes das partes", como forma de bem estruturar a

\footnotetext{
${ }^{26}$ Cf. Gozzoli, op. cit., p. 8-9.

${ }^{27}$ Cf. Panofsky, op. cit., p. 15.
} 
exposição; e, obviamente, a clareza e força probatória, entendidas aqui como uma relação suficiente de reciprocidade entre o que se mostra e o que se comprova a partir disso. Como complemento a estes prérequisitos para a correta exposição escolástica há ainda as similitudines de Tomás de Aquino, ou seja, uma espécie de analogia, com o uso de palavras adequadas, visando à melhor compreensão dos conceitos expostos.

É nesse sentido que, ao observarmos a estrutura de uma catedral gótica, podemos aplicar o conceito escolástico de completude, pois não há nada sobrando, nem nada que falte. Elementos como a cripta, as galerias, e as torres, com exceção daquelas frontais, foram eliminados, em nome da clareza e da síntese exata de todo o conhecimento cristão, seja no aspecto teológico, como também no natural, histórico e moral.

Da mesma forma é facilmente observado um "princípio de divisibilidade progressiva", que consiste em uma homologia entre as partes que constituem uma construção gótica, demonstrando assim que todas as partes que compõem a estrutura situam-se dentro de um mesmo nível lógico. $\mathrm{O}$ exemplo mais claro dessa divisão progressiva, que pode sem dúvida ser associada à esmerada divisão e subdivisão de um tratado escolástico bem estruturado, está nos

[...] suportes [que] eram divididos em pilar principal, colunas adossadas, colunas adossadas secundárias e colunetas novamente subordinadas a estas últimas; a caixilharia das janelas, os trifórios e as arcadas cegas eram divididas em suportes e perfis de primeira, segunda ou terceira ordem; nervuras e arcos eram subdivididos numa série de perfis. ${ }^{28}$

Desta forma, assim como estamos habituados a fazer divisões sucessivas em um trabalho acadêmico, de forma a deixá-lo claro e organizado, os construtores, por influência da escolástica, aplicaram o mesmo princípio às suas catedrais.

\section{IV.3. Manifestatio e concordantia}

Em relação às duas premissas básicas da escolástica, aplicadas à arquitetura das catedrais góticas em seu apogeu, Panofsky diz:

Enquanto o primeiro, a manifestatio, nos ajuda a entender a imagem fenomênica da arquitetura clássica do apogeu gótico, o segundo, a concordantia, ajuda a compreender a gênese do apogeu gótico clássico. ${ }^{29}$

\footnotetext{
${ }^{28}$ Cf. Panofsky, op. cit., p. 34.

${ }^{29}$ Cf. Panofsky, op. cit., p. 46.
} 
Ou seja, a manifestatio, compreendida como a maneira clara de explicitar os conteúdos relacionados à fé cristã à luz da razão, determinou a mesma clareza de linhas e divisão dos elementos constitutivos de uma obra arquitetônica gótica. Como exemplo, Panofsky cita o portal central da fachada ocidental da catedral de Notre-Dame em Paris, com os doze apóstolos representados em divisões simétricas de dois grupos no tímpano da catedral. A simetria, sem dúvida alguma, era algo caro aos escolásticos e manifestou-se também na arquitetura gótica.

Já a concordantia, em se tratando da necessidade de conciliação de "possibilidades contraditórias" presente na filosofia escolástica, expressa em sua forma mais completa através do método de Abelardo de Sic et $\operatorname{Non}^{30}$ até chegar-se a uma síntese, uma solução, parece ter sido outro fator a influenciar a arquitetura gótica. Resumidamente, este método consistia em aceitar as possíveis contradições dos textos de autoria de filósofos, dos padres da Igreja e até mesmo das escrituras sagradas. No entanto, como passo posterior à aceitação da existência destas contradições, passava-se então a tentativa de conciliá-las, que se dava através do método de arrolamento de uma série de autoridades (autorictates) em uma espécie de conjunto (videtur quod) que era colocado em oposição a outro rol de autoridades (sed contra). Como resultado deste confronto entre duas autoridades com comentários opostos, conflitantes, a respeito de um tema, era produzida como solução a respondeo dicendium.

Um fato notório que demonstra de maneira bastante convincente esta relação, levando-se em consideração que as construções românicas do passado aqui funcionavam como auctoritas, é a solução definitiva que os mestres-construtores encontraram para alguns problemas típicos da origem da arquitetura gótica. São três quaestiones cruciais, que, ao serem resolvidas definitivamente, caracterizaram e diferenciaram de vez esta nova forma de arquitetura em relação às construções românicas de antes. As quaestiones que tiveram então o seu respondeo dicendium dado pelos arquitetos góticos foram: a rosácea na fachada ocidental, ao substituir a janela que sempre existiu por uma estrutura circular que era estranha ao gosto gótico; a estrutura da parede debaixo do clerestório,

\footnotetext{
${ }^{30}$ Famoso tratado onde Abelardo arrola 158 itens importantes, desde suicídio até concubinato, que são confrontados, em uma relação dialética, a partir de visões conflitantes das autoridades e conciliados por fim. Entre outras, a importância deste texto está em demonstrar claramente a visão dos escolásticos e que a fé poderia buscar apoio na razão.
} 
com a criação do trifório que conjugou o Sic românico de Caen com o Non gótico de Amiens; e a conformação dos pilares da nave central, que deixaram de ser somente associados a formas angulares e passaram a utilizar o núcleo cilíndrico. ${ }^{31}$ É importante destacar que Panofsky defende que todas essas mudanças ocorreram - ainda que sendo sabida a importância do hábito mental criado pela filosofia escolástica - de forma consciente, sendo aplicadas de forma racional pelos mestresconstrutores.

De acordo com Panofsky, ${ }^{32}$ a influência do princípio da concordantia sobre as obras do apogeu do gótico é tão grande que "a dialética escolástica desenvolveu o pensamento arquitetônico a um ponto em que ele quase deixa de ser arquitetônico". É quase como afirmar que os construtores das catedrais não estavam construindo igrejas, mas fazendo filosofia em pedra e vidro.

\section{Um registro em pedra e vidro}

Quando Rossi fala na individualidade de um fato urbano, ${ }^{33}$ nos sentimos tentados a analisar a origem da arquitetura gótica justamente por sua ligação estreita com o urbanismo medieval da Baixa Idade Média, conforme visto anteriormente. São colocadas pelo autor as questões que envolvem a origem deste fato urbano, no sentido de se procurar o acontecimento que o deflagrou e o signo que o fixou no tempo. $\mathrm{O}$ acontecimento, aqui, em se tratando da arquitetura gótica, parece-nos ser o surgimento da filosofia escolástica, que promoveu uma nova esquematização do pensamento que se estendeu para toda a sociedade, tendo decisiva importância aí o processo de urbanização e de estabelecimento de centros de estudos nas cidades. O signo desta mudança histórica está expresso na nova forma de arquitetura, que representa tanto uma nova espiritualidade quanto uma nova relação

\footnotetext{
${ }^{31}$ Para um maior aprofundamento no tema, recomendamos a leitura do capítulo V de Arquitetura gótica e escolástica, onde Panofsky examina detalhadamente todas estas novas características da arquitetura gótica, comparando-as com os valores da arquitetura românica e demonstrando a relação da filosofia escolástica com a resolução destes problemas.

${ }^{32}$ Cf. Panofsky, op. cit., p. 62.

${ }^{33}$ Cf. Rossi, op. cit., p. 151.
} 
entre a fé e a razão. Victor Hugo diz em seu livro Notre Dame de Paris, ${ }^{34}$ não por acaso um romance que tem a famosa catedral gótica como personagem, que nenhum pensamento ou ideal humano até o século XV deixou de ser gravado na pedra, na arquitetura. Diz que "nos seis mil primeiros anos do mundo, desde o pagode mais imemorial do Indostão até a catedral de Colônia, a arquitetura foi a grande escritura do gênero humano". ${ }^{35}$ Neste sentido, não podemos deixar de refletir na grandiosidade da arquitetura gótica em promover este registro. Tantos séculos depois que a última cidade romana deixara de existir, ao menos como uma cidade romana, a Europa ocidental e cristã, e mais que cristã, católica, voltava a se movimentar em direção ao urbanismo. De igual maneira, o pensamento até então mais obscurantista passava agora a flertar com a razão, sem, no entanto, desprezar a religião, muito pelo contrário. O desejo dos clérigos escolásticos é legitimar ainda mais o seu credo pelo argumento filosófico. Estes movimentos intensos não poderiam deixar de ser registrados, e, como bem disse Hugo, "até Gutenberg, a arquitetura é a escrita principal, a escrita universal". ${ }^{36}$ A catedral gótica é o signo claro e eloquente do que estava acontecendo naquele período e naquele lugar:

A arquitetura foi até o século XV o registro principal da humanidade; fato é que neste intervalo não apareceu no mundo pensamento um pouco complicado que não se tenha feito edifício; que toda a ideia popular, como toda a lei religiosa, tem tido os seus monumentos; que o gênero humano, enfim, não tem pensado nada importante que o não tenha escrito em pedra. E por quê? Porque todo o pensamento, quer religioso, quer filosófico, tem interesse em se perpetuar; porque a ideia que agitou uma geração quer agitar outras e deixar vestígios. Ora, que precária imortalidade a de um manuscrito! Como um edifício é um livro bem mais sólido, duradouro e resistente! ${ }^{37}$

\footnotetext{
${ }^{34}$ Notre Dame de Paris é um romance de Victor Hugo publicado em 1831. No entanto, quando saiu a primeira edição foram suprimidos três capítulos que haviam sido perdidos pela gráfica durante o processo de produção do livro. Posteriormente, os cadernos contendo estes capítulos foram encontrados e foram incluídos nas novas edições. É exatamente um destes capítulos que trata, filosoficamente, desta questão da arquitetura ter sido a mais importante forma de registro humano até o século XV, quando surge o livro impresso. Para Hugo isto [o livro impresso] há de matar aquilo [a arquitetura].

${ }^{35}$ Cf. Hugo, op. cit., p. 221.

${ }^{36}$ Cf. Hugo, op. cit., p. 225.

${ }^{37}$ Cf. Hugo, op. cit., p. 227.
} 
É impossível não pensar na opulência de uma catedral gótica, com suas formas inovadoras e tamanho descomunal, atuando exatamente como a ideia de Victor Hugo de que o livro de pedra é muito mais eloquente e eterno do que um simples manuscrito que perecerá em algumas décadas. Se concordarmos com o autor, perceberemos que neste caso o pensamento a se preservar é mais poderoso ainda, pois é, ao mesmo tempo, filosófico e religioso. A arquitetura gótica foi produzida pela filosofia escolástica, que, por sua vez, teve sua razão de existir na religião que procurava pensar, religião esta que já estava há mais de dez séculos produzindo edifícios que inscreviam de forma duradoura, na história, as suas doutrinas.

Neste mesmo sentido, podemos afirmar que uma religião que tem a "necessidade da lembrança como tarefa religiosa fundamental", seja pela repetição festiva da paixão de Cristo, seja pelo simples estudo bíblico, que afinal de contas trata do exame de fatos do passado descritos literariamente que estão na origem da própria Igreja, também se utiliza do expediente arquitetônico, tanto para reproduzir esta lembrança quanto para enviar sinais aos fiéis. Vejamos o que diz Maiolino, a respeito da forma dada às catedrais:

A planta da igreja gótica era em forma de cruz latina. Sua implantação era feita de forma que a nave e a capela-mor se situassem no braço longitudinal no sentido Leste-Oeste. Assim o altar-mor ficaria a Leste, onde nasce o sol, o que costumou-se chamar de cabeceira. A fachada ocidental ficaria preferencialmente a Oeste, onde o sol se põe, numa nítida alusão à necessidade do homem de percorrer um longo caminho para chegar até Deus. Desta forma, o braço do transepto ficaria no sentido Norte-Sul, sendo o lado do Evangelho para o Norte e o lado da Epístola para o Sul. A parte inferior do braço longitudinal da cruz era normalmente dividida em três naves, sendo a central maior que as outras duas, tanto em altura quanto em largura. ${ }^{39}$

É interessante notar como a arquitetura pode conjugar estas duas formas de comunicação e de contato entre presente, passado e futuro. Há, em uma mesma obra arquitetônica, conforme a descrição de Maiolino, a recordação das escrituras sagradas, um ideal de comportamento expresso na direção da construção e a perenização do

\footnotetext{
${ }^{38}$ Cf. Le Goff, op. cit., 1994, p. 444.

${ }^{39}$ Cf. Maiolino, op. cit., p. 12.
} 
símbolo máximo do cristianismo, que é a cruz, plantada naquele local para toda a eternidade, à vista de todas as gerações vindouras. ${ }^{40}$

Segundo Pignatari, "nem toda arquitetura é apenas pedra, nem toda música é apenas som", ${ }^{41}$ o que nos faz imaginar uma certa consciência e racionalidade que se expressam através da construção de uma catedral gótica. Fazendo a análise de alguns dos fatores que abordamos neste trabalho como, por exemplo, a filosofia escolástica, a recordação característica da religião católica e a necessidade de se preservar em monumentos o pensamento filosófico e religioso, percebemos que faz muito sentido a afirmação do autor de que:

[...] a mensagem arquitetônica - especialmente quando entendida como mensagem de massa: o assentamento humano, a cidade - é endereçada, antes de mais nada a não-arquitetos, ou seja, a receptores e interpretantes cujo código principal não é o arquitetônico, mas que, no entanto (de maneira leiga, digamos), só podem absorver a mensagem decodificando-a, em primeiro lugar, segundo o código arquitetônico. $^{42}$

Mesmo com toda a consciência com que os mestres-construtores aplicaram os princípios escolásticos em suas obras, na verdade o mais importante ainda é a mensagem que a construção vai levar adiante àqueles que são leigos, no caso, o imenso público fiel que vai fazer o uso efetivo da construção durante as missas e outras celebrações religiosas. Daí a importância de simbolizar e de significar para os habitantes daquele espaço urbano, que vão utilizar as dependências da catedral, a cruz, o caminho que o homem deve percorrer para ser mais justo, a mudança de uma estrutura militante românica para uma triunfante obra gótica. Representa-se aqui, além de uma mudança de gosto, uma grande e

\footnotetext{
${ }^{40}$ Esta constatação é ainda mais importante quando temos em mente que o conhecimento, para os historiadores medievais, era entendido como a apreensão imediata de um dado. Conhecer significava ver com os próprios olhos, tocar com a próprias mãos e ouvir com os próprios ouvidos (cf. Rui, op. cit., p. 214). Nada mais adequado para a promoção desta experiência cognitiva que a solidez de uma catedral, aliada à música religiosa, às iconografias, à estatuária, aos vitrais e à sua luz de aspecto celeste. A união de todos estes elementos em um mesmo edifício certamente é capaz de marcar indelevelmente o entendimento acerca da cristandade em um indivíduo inserido em um contexto profundamente religioso como a sociedade medieval.

${ }^{41}$ Cf. Pignatari, op. cit., p. 155.

${ }^{42}$ Cf. Pignatari, op. cit., p. 155.
} 
importante modificação mental daqueles homens e mulheres que viveram na Europa nos séculos XII e XIII. O signo destas mudanças foi expresso, com toda a sua complexidade - histórica, filosófica, religiosa, urbana e social - na arquitetura gótica, surgida não somente como uma substituta da arquitetura românica, mas como uma etapa posterior, diretamente ligada aos sentimentos humanos, cada vez mais urbanos, daquela sociedade em transição. E aí está a importância da arquitetura como fonte historiográfica, pois é do "confronto histórico e dialético, que permanece mesmo depois que os emissores e receptores originais já tenham desaparecido há séculos ou milênios, que flui o significado da arquitetura". ${ }^{43}$ A obra arquitetônica, por seu caráter de permanência, dialoga não só com aquelas gerações que a viram nascer, como com todas as outras que vêm a conhecê-la, e, desta forma, segue enviando sua mensagem continuamente, com todas as ressignificações que ela possa ter.

\section{Considerações finais}

As transformações mentais ocorridas durante a Idade Média, no período de avanço do urbanismo, em uma Europa que havia passado quase mil anos apenas com raras e medíocres cidades, tiveram forte impacto sobre as estruturas materiais desta sociedade, incluída aí a nova forma de arquitetura desenvolvida, que veio a ser chamada "gótica".

Mas o que constituem exatamente estas transformações mentais?

O desenvolvimento das cidades neste período provocou alterações profundas em todos os âmbitos da sociedade. Como temos por objetivo neste trabalho analisar a arquitetura gótica, que está intimamente ligada ao fator religioso, pois surge como a arquitetura de catedrais, devemos atentar para o caráter religioso da sociedade e para as transformações que o impactam diretamente.

Em primeiro lugar, podemos afirmar que, com o deslocamento do ensino, até então exclusividade dos mosteiros mais isolados, para as cidades, houve uma expansão do conhecimento e da atividade intelectual para um maior espectro da sociedade; ao menos, as reflexões que se produziam eram mais facilmente percebidas pela população leiga, embora esta, em sua grande maioria, permanecesse iletrada. Houve então o aparecimento da filosofia escolástica, que pretendia conjugar a

${ }^{43}$ Cf. Pignatari, op. cit., p. 156. 
fé com a razão, usando a última para legitimar a primeira. Este fenômeno, que tem as suas características metodológicas específicas, tais como clareza, esquematização, conciliação de interpretações conflitantes de autoridades filosóficas ou teológicas, promoveu uma nova forma de pensar - ou uma nova forma de organizar o pensamento - que não se restringiu a quem estava dentro das escolas ou diretamente ligado ao ministério da Igreja. Esta nova visão filosófica do mundo e da religião passou a se estender também às camadas populares, como ocorre, por exemplo, hoje em dia: mesmo um leigo no assunto utiliza termos como internet, e-mail, iPOD, embora não necessariamente saiba como funcionam, ou até nunca tenha utilizado de maneira profissional qualquer uma destas ferramentas tecnológicas. A filosofia escolástica ecoou por toda aquela sociedade urbana medieval.

No entanto, ela sem dúvida teve influência direta sobre aqueles que eram obrigados, por força de seu ofício, a trabalhar diretamente com aqueles que produziam e reproduziam estes conhecimentos; falamos aqui dos mestres-construtores em contato direto com os clérigos que os instruíam acerca da construção de uma nova igreja ou da produção iconográfica a ser utilizada. Esta influência se deu, como visto neste trabalho, na organização dos elementos constitutivos de uma obra arquitetônica gótica, conforme os preceitos escolásticos que a princípio eram aplicados aos seus tratados. Portanto, temos aqui uma revolução arquitetônica que está estreitamente ligada a um novo fator de entendimento teológico.

Com a revolução urbana, houve o desenvolvimento e divulgação da filosofia escolástica que tornou possível a criação da arquitetura gótica. De igual maneira, e tendo em mente o caráter visual do homem medieval que apreendia o novo através da visualização direta, talvez em boa parte pelo baixo grau de alfabetização que era o estado comum da maioria das populações, excetuados os clérigos, os quais tinham acesso à leitura e à escrita, concluímos que as catedrais góticas representaram simultaneamente os preceitos escolásticos, a influência da filosofia na arquitetura e a transição de gosto e de mentalidade que ocorria naquele instante histórico.

Como religião direta e essencialmente influenciada pela recordação, o cristianismo medieval inscreveu na pedra os ensinamentos da religião e sinalizou aos fiéis estes ensinamentos através das formas externas e internas de uma catedral gótica. Da mesma forma que uma obra arquitetônica não pode ser transposta para outro lugar, justamente por surgir a partir das especificidades culturais, religiosas, sociais e mentais do local onde é erguida, podemos compreender que a arquitetura gótica, nos séculos XII e XIII, época de seu apogeu, 
representou a mentalidade daquela sociedade em transição. Passava-se do românico ao gótico porque se passava da Igreja militante para a Igreja triunfante. A luta contra o mal, de antes, dá lugar a uma nova relação, mais metafísica, do homem com Deus. Uma relação de transcendentalidade, expressa de maneira eloquente e inequívoca na verticalidade gótica que eleva aquilo que é terreno ao âmbito celestial.

\section{Referências}

BRACONS, J. Saber ver a arte gótica. Trad. Jamir Martins. São Paulo: Martins Fontes, 1992.

CHOAY, F. O urbanismo: utopias e realidades, uma antologia. 6. ed. Trad. Dafne Nascimento Rodrigues. São Paulo: Perspectiva, 2007.

DE BONI, L. A. (org.). A ciência e a organização dos saberes na Idade Média. Porto Alegre: EDIPUCRS, 2000.

AUDI, R. (Dir.) Dicionário de filosofia de Cambridge. Trad. Edwino Aloysius Royer. São Paulo: Paulus, 2006.

FOCILLON, H. A arte do ocidente: a Idade Média românica e gótica. 2. ed. Trad. José Saramago. Lisboa: Estampa, 1993.

GOMBRICH, E. H. A história da arte. Trad. Álvaro Cabral. Rio de Janeiro: LTC, 2008.

GOMES, V. S. Gótico, a Escolástica de pedra. Disponível em: <http:// www.arautos.org.br/artigo/18193/Gotico-a-Escolastica-de-pedra.html > . Acesso em: 12/10/2011.

GOZZOLI, M. C. Como reconhecer a arte gótica. Trad. Carmen de Carvalho. Lisboa: Edições 70, 1986.

HUGO, V. Nossa Senhora de Paris. 2. ed. Trad. Não informado. Porto: Chardron,1945.

JOHNSON, S. Emergência: dinâmica de rede em formigas, cérebros, cidades e softwares. Trad. Maria Carmelita P. Dias. Rio de Janeiro: Zahar, 2003.

LE GOFF, J. As raízes medievais da Europa. Trad. Jaime A. Clasen. Petrópolis: Vozes, 2007.

LE GOFF, J. O apogeu da cidade medieval. Trad. Antônio de Pádua Danes. São Paulo: Martins Fontes, 1992.

LE GOFF, J. História e memória. Trad. Nilson Moulin Louzada. Campinas: UNICAMP, 1994.

LOPEZ, R. S. A cidade medieval. Lisboa: Presença, 1988.

MAIOLINO, C. F. A arquitetura religiosa neogótica em Curitiba entre os anos de 1880 e 1930. Dissertação de mestrado. Porto Alegre: UFRGS, 2007.

PANOFSKY, E. Arquitetura gótica e escolástica: sobre a analogia entre arte, filosofia e teologia na Idade Média. Trad. Wolfe Höernke. São Paulo: Martins Fontes, 1991. 
PIGNATARI, D. Semiótica da arte e da arquitetura. São Paulo: Cultrix, 1981.

PUGIN, A. W. N. O belo ontem. In: CHOAY, F. (org.). O urbanismo: utopias e realidades, uma antologia. 6. ed. Trad. Dafne Nascimento Rodrigues. São Paulo: Perspectiva, 2007, p. 117-120.

ROSSI, A. A arquitetura da cidade. Trad. Eduardo Brandão. São Paulo: Martins Fontes, 1995.

RUI, A. J. A elaboração de História na Idade Média: o exemplo de Alfonso X, o Sábio. In: DE BONI, L. A. (org.). A ciência e a organização dos saberes na Idade Média. Porto Alegre: EDIPUCRS, 2000, p. 211-217.

SILVEIRA, E. A. Urbanismo e religiosidade na Idade Média. Estudos Ibero-Americanos, Porto Alegre, vol. 24, n. 1, p. 165-180, 1998. 